- Title. NT-pro BNP - a Marker for Worsening Respiratory Status and Mortality in Infants and Young Children with Pulmonary Hypertension

- Short title. NT-pro BNP in Pulmonary Hypertension

-Author names, academic degrees, and affiliations. Shahnawaz M. Amdani, M.B.B.S, M.D. ${ }^{\pi}$; Muhammad Umair M. Mian, M.D.; ${ }^{\dagger}$ Ron L. Thomas, PhD ${ }^{\#}$; Robert D. Ross, M.D.*

${ }^{\pi}$ Division of Pediatric Cardiology, St. Louis Children's Hospital, Washington University School of Medicine, St. Louis, Missouri.

†'Division of Pediatrics, The Carman and Ann Adams Department of Pediatrics, The Children's Hospital of Michigan, Wayne State University School of Medicine, Detroit, Michigan.

${ }^{\#}$ Division of Biostatistics, The Carman and Ann Adams Department of Pediatrics, The Children's Hospital of Michigan, Wayne State University School of Medicine, Detroit, Michigan.

* Division of Pediatric Cardiology, The Carman and Ann Adams Department of Pediatrics, The Children's Hospital of Michigan, Wayne State University School of Medicine, Detroit, Michigan.

\title{
- Corresponding author.
}

Robert D. Ross, M.D.

Division of Cardiology, Carman and Ann Adams Department of Pediatrics, The Children's Hospital of Michigan,

3901 Beaubien Blvd, Detroit, MI 48201-2119, USA

Phone: 313-745-5956

This is the author manuscript accepted for publication and has undergone full peer review but has not been through the copyediting, typesetting, pagination and proofreading process, which may lead to differences between this version and the Version of record. Please cite this article as doi:10.1111/ chd.12601. 
Fax: +1(313)993-0894,

E-mail: rross@dmc.org

Conflicts of interest: The authors have no conflicts of interest to disclose.

Funding: This research did not receive any specific grant from funding agencies in the public, commercial, or not-for-profit sectors.
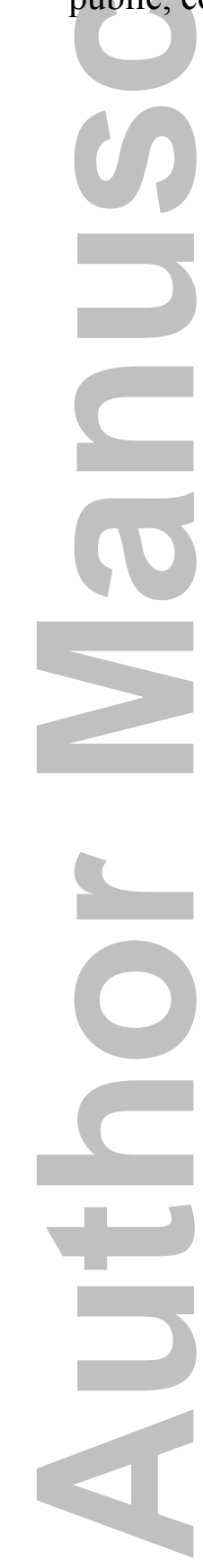
Aim: To evaluate predictors of morbidity and mortality in pediatric patients with $\mathrm{PH}$, laboratory and echocardiographic measures of pulmonary hypertension were analyzed.

Methods: Retrospective review of all infants and children $<2$ years of age with $\mathrm{PH}$ from January 2011 to August 2016 was conducted. Correlations were determined using Spearman's rank correlation coefficients. Differences in characteristics between survivors and non-survivors were analyzed and Kaplan-Meier survival curves were generated.

Results: Of 56 patients, majority were extremely premature; of African-American ethnicity; and had bronchopulmonary dysplasia. Patients who died were more likely to have underlying congenital heart disease; have a higher increase in $\mathrm{pCO} 2$ with a corresponding greater mean percentage decrease in $\mathrm{pH}$ and percentage rise in NT-pro BNP during PH exacerbations; more likely to have been on pulmonary hypertension medications; and have a higher RVSP/SBP (\%) ratio and S/D ratio. There were positive correlations between percentage rise in NT-pro BNP and pCO2; NT-pro BNP and $\mathrm{RVSP} / \mathrm{SBP}(\%)$ ratio; and $\mathrm{RVSP} / \mathrm{SBP}(\%)$ ratio and $\mathrm{S} / \mathrm{D}$ ratio.

Conclusions: Infants and young children with pulmonary hypertension have increased morbidity and mortality. NT-pro BNP is a useful biomarker for both respiratory exacerbations and mortality, and RVSP/SBP (\%) ratio and S/D ratio are echocardiographic identifiers for increased mortality.

Keywords: pulmonary hypertension; morbidity, mortality; NT-pro BNP; pCO2 


\section{Introduction}

Brain natriuretic peptide (BNP) is an amino acid that is secreted in response to volume or pressure overload to the ventricles in the heart. $(1,2)$ BNP counteracts the renin angiotensin system and causes diuresis, natriuresis and systemic (arterial and venous) vasodilatation. (3) This in turn relieves the pressure and volume load to the ventricles. Both BNP and its precursor N terminal - pro BNP (NT-pro BNP) have been used extensively in the adult population to identify patients with myocardial dysfunction $(2,4)$, and to gauge response to anti-congestive treatment (5) and overall outcomes.

Since BNP has a shorter half-life ( 20 minutes) compared to NT-pro BNP ( 1-2 hours) (6), NT-pro BNP may reflect more consistent concentrations in order to evaluate pressure/volume overload to the ventricles. These cardiac biomarkers have been used in children as well and have correlated with ventricular dysfunction and mortality in patients with heart failure. $(1,7)$ Moreover, they have been used to predict low cardiac output syndrome (LCOS), and post-operative mortality in patients undergoing cardiac surgery.

At birth, the values of both BNP and NT-pro BNP rise and then decline in early infancy.(8) It has been found that NT-pro BNP levels are higher in neonates with a hemodynamically significant patent ductus arteriosus (PDA) (9), bronchopulmonary dysplasia (BPD) (10) and persistent pulmonary hypertension (PH) of the newborn.(11)

The purpose of this study was to evaluate predictors of inpatient morbidity and mortality in infants and young children with $\mathrm{PH}$ requiring hospitalization. Over the last several years, author RDR observed a trend for an increase in NT-pro BNP concentrations with exacerbations in respiratory status in children with pulmonary hypertension (Figures 1a-1c). The hypothesis generated from these observations was that 
there is a correlation between acute rises in $\mathrm{pCO} 2$ as a surrogate for an exacerbation of respiratory status (as in acute worsening of $\mathrm{PH}$, new atelectasis, pneumonia, pneumothorax or pleural effusion) and NT-pro BNP concentrations. Therefore, the aim of this study was to assess the relationship between laboratory and echocardiographic measures of pulmonary hypertension and respiratory status as indicated by changes in $\mathrm{PCO} 2$ and $\mathrm{pH}$ and to assess these variables for predictors of mortality.

\section{Methods}

\section{Study population}

The electronic database was queried to identify all infants and children $<2$ years from January 1st 2011 to August 31st 2016 who were hospitalized in the neonatal or pediatric intensive care unit with a diagnosis of pulmonary hypertension. A detailed chart review was conducted to obtain demographic data [age, sex, ethnicity]; clinical information [height, weight, body surface area (BSA), underlying diagnosis, systolic blood pressure, total hospital length of stay, history of intubation, duration of intubation, history of tracheostomy, history of extracorporeal membrane oxygenation (ECMO) use, discharge mortality status] and medication history (use of sildenafil, milrinone, nitric oxide).

Patients $\geq 2$ years of age; those with incomplete documentation on review of medical records or incomplete echocardiographic information were excluded from the study.

Approval of the study and waiver of consent were obtained from the Wayne State University Institutional Review Board and Children’s Hospital of Michigan.

\section{Laboratory data}


All NT-pro BNP values that were collected were included for analysis. These were obtained at the discretion of the physician caring for the child or at the request of the $\mathrm{PH}$ consultant. To avoid using isolated laboratory values which might not reflect true trends, we collected 48-hour (24 hours before and after NT-pro BNP collection) pH and pCO2 values, to correlate with respiratory status around the times of NT-pro BNP sampling. The lowest values, highest values and 48-hour averages of $\mathrm{pH}$ and $\mathrm{pCO} 2$ were subsequently calculated. The percentage change in NT-pro BNP value during PH exacerbation was calculated. Also, percentage changes in $\mathrm{pCO} 2$ and $\mathrm{pH}$ were calculated during the time NT-pro BNP was collected to capture acute changes in respiratory status.

\section{Echocardiography data}

Transthoracic two-dimensional and Doppler echocardiographic studies were performed using a Philips Sono IE 33 machine (Philips Inc Andover, MA). Only studies completed within 72 hours of the NT-pro BNP collection were included for analysis to achieve best possible correlation with echocardiographic parameters. A single pediatric cardiologist, who was blinded with respect to respiratory status, laboratory results and the patients' prior echocardiogram reports and diagnoses, retrospectively reviewed all echocardiograms. Echocardiographic 2 dimensional apical views were used to assess right ventricular $(\mathrm{RV})$ size as described by prior studies. $(12,13)$ In the presence of tricuspid regurgitation (TR) and absence of right ventricular outflow tract obstruction, apical or parasternal long axis views were used to estimate systolic pulmonary artery pressure using modified Bernoulli's equation. (14) The highest estimate of velocity obtained was used for the study. RV systolic function was assessed by utilizing Tricuspid 
annular plane systolic excursion (TAPSE) (15) and systolic to diastolic time (S/D) ratio was evaluated from the TR jet using method described previously. $(16,17)$

\section{Statistical analysis}

Descriptive statistics were calculated using mean and $95 \%$ confidence intervals or medians and interquartile ranges for continuous variables and percentages for categorical variables. Patients in our study were divided into two groups - survivors (Group 1) and non-survivors (Group 2). Student's t-test was used for normally distributed numeric variables in the intergroup analysis, Mann-Whitney U test was used for non-normally distributed numeric variables, and chi-square test was used for categorical variables in the intergroup analysis. Correlations between various laboratory (NT-pro BNP, pCO2) and echocardiographic parameters [RVSP/SBP (\%) ratio, S/D ratio] were determined using Spearman's rank correlation coefficients. ROC curves were constructed for four variables [Highest NT-pro BNP value (pg/ml); \% change in NT-pro BNP value; RVSP/SBP ratio (\%); and S/D ratio], and cut-offs with highest sensitivity and specificity identified.

Subsequent Kaplan-Meier analysis with log-rank test was utilized to analyze patient survival for these variables. A p value of $<0.05$ was considered statistically significant. Statistical analysis was performed using SPSS Version 24.0 (IBM Inc., Chicago, IL).

\section{Results}

\section{Baseline characteristics}

Of 151 charts reviewed, 56 met inclusion criteria ( 80 were $>2$ years of age, 10 with missing laboratory values, 5 with echocardiograms not obtained within 72 hours of the 
laboratory values). The majority of the patients were extremely premature $(<28$ weeks gestation) at birth (28/56, 50\%); of African American ethnicity (37/56, 66.1\%), and there was an equal gender distribution in the study group. (Table 1) The most common underlying diagnosis was bronchopulmonary dysplasia $(35 / 56,62.5 \%)$ followed by congenital heart disease $(4 / 56,7.1 \%)$. In the patients with PH, various forms of support were needed - intubation and mechanical ventilation (49/56, 87.5\%); tracheostomy (23/56, 41.1\%); sildenafil (42/56, 75\%); milrinone $(23 / 56,41.1 \%)$; nitric oxide $(32 / 56$, 57\%); and ECMO (4/56, 7\%). The right ventricular systolic pressure was severely increased in $21 / 56(37.5 \%)$ of the population. Of the 56 patients in the study, $9(16.1 \%)$ patients died.

Comparing pediatric patients with pulmonary hypertension who survived (Group 1) vs. non-survivors (Group 2).

There was no difference between the 2 groups with regards to gestational age at birth, height, weight, body surface area or ethnicity (Table 2). Although females with PH had a higher likelihood of dying (77.8 vs. 44.7\%), this did not achieve statistical significance. There was higher mortality in patients with $\mathrm{PH}$ who had congenital heart disease compared to those with structurally normal hearts $(33.1$ vs. $2.1 \%, p=0.01)$. The difference in percentage rise in NT-pro BNP during an acute fall in $\mathrm{pH}$ was significantly higher in Group 2 (U=35, Z-score -3.02, $\mathrm{p}<0.01)$. Moreover, the patients who died had significantly higher mean percentage decrease in $\mathrm{pH}$ and higher increase in $\mathrm{pCO} 2$ during an exacerbation in respiratory status ( $14 \pm 32$ vs. $2.5 \pm 2.1, \mathrm{p}=0.01 ; 406 \pm 247$ vs. $208 \pm$ $150, \mathrm{p}<0.05)$. Patients who died were more likely to have been on pulmonary 
hypertension medications - sildenafil (100 vs. $70.2 \%, \mathrm{p}<0.05)$, milrinone (77.8 vs. 34\%, $\mathrm{p}<0.05)$ and nitric oxide (88.9 vs. $51.1 \%, \mathrm{p}<0.05)$.

Echocardiographic evaluation revealed that patients who died had a significantly higher $\mathrm{RVSP} / \mathrm{SBP}(\%)$ ratio $(76 \pm 37$ vs. $46 \pm 43, \mathrm{p}=0.05)$ and $\mathrm{S} / \mathrm{D}$ ratio $(2.2 \pm 0.9$ vs. $1.6 \pm 0.4$ $\mathrm{p}<0.01$ ). Moreover, these Group 2 patients were more likely to have right to left or bidirectional shunting compared to Group $1(\mathrm{p}<0.05)$.

\section{ROC curves and Survival analysis}

ROC curve analysis identified the following optimal cut-off points: highest NT-pro BNP value (pg/ml) - 8915; \% change in NT-pro BNP value during PH exacerbation- 1291; RVSP/SBP (\%) ratio- 64 ; $\mathrm{S} / \mathrm{D}$ ratio- 1.7.

Patients with NT-pro BNP values $>8915 \mathrm{pg} / \mathrm{ml}$ had worse survival compared to patients with NT-pro BNP values $\leq 8915 \mathrm{pg} / \mathrm{ml}[13$ (8.5-17.5) vs. 20.3(17.9-22.6) months,

$\mathrm{p}=0.01]$. (Figure 2) Patients with increase in NT-pro BNP values during $\mathrm{pH}$ exacerbation of $\geq 1291 \%$ tended to have worse survival compared to patients with a change $<1291 \%$ $(p=0.12)$. (Figure 3) Also, patients with RVSP/SBP (\%) ratio $\geq 64$ tended to have worse survival compared to patients with RVSP/SBP (\%) ratio <64 [16.1 (12.2-20) vs. 18.6 (15.2-22.1) months, $p=0.38$ ]. (Figure 4) In addition, those with $S / D$ ratio $>1.7$ had worse survival compared to patients with $\mathrm{S} / \mathrm{D}$ ratio $\leq 1.7$ [13.4(9.3-17.6) vs. $21.5(19.9-23.1)$ months, $\mathrm{p}<0.01]$. (Figure 5)

There was a significant positive correlation between percentage rise in NT-pro BNP and percentage rise in $\mathrm{pCO} 2$ during exacerbations in respiratory status $(r=0.40, \mathrm{p}=0.01)$.

There was a similar correlation between NT-pro BNP value and RVSP/SBP (\%) ratio $(\mathrm{r}=0.44, \mathrm{p} \leq 0.01)$; and $\mathrm{RVSP} / \mathrm{SBP}$ ratio and $\mathrm{S} / \mathrm{D}$ ratio $(\mathrm{r}=0.42, \mathrm{p}<0.01)$. 


\section{Discussion}

With the growing number of extremely premature births surviving the neonatal period, there has been a steady increase in long-term survivors with chronic lung disease such as BPD. $(18,19)$ This increased incidence of BPD is secondary to prolonged mechanical ventilation required by the severe prematurity due to respiratory distress syndrome and deficient surfactant levels. The effect of this is chronic barotrauma, frequent pneumonias and other respiratory complications in these extremely premature infants. In this study, half of the population was extremely premature who are at higher risk for developing pulmonary hypertension secondary to BPD. $(20,21)$

Children with PH have increased morbidity and mortality compared to those without PH. $(22,23)$ Of 56 children with PH in this study, most required some support to help them through the acute phase of PH exacerbation in the form of mechanical ventilation and pulmonary vasodilator medication. The patients who were on these types of support were more likely to die, particularly those who required milrinone and inhaled nitric oxide. The mortality overall was $\sim 16 \%$. Other studies have shown similar high mortality rates in children with pulmonary hypertension, with the highest risk in those with congenital diaphragmatic hernia. $(21,24,25)$

BPD was the major reason for PH in this study. Although congenital heart disease

(CHD) was much less common in this cohort, its presence was associated with a $\sim 16$ fold higher mortality. In the latest classification of pulmonary hypertension in children, CHD has been labeled as an independent diagnosis. Certain types of CHD increase the propensity for developing $\mathrm{PH}$ in the neonatal period including obstructed total pulmonary 
venous return, scimitar syndrome and hypoplastic left heart syndrome with a restrictive atrial septal communication. It has been shown that $\mathrm{PH}$ in these patients increases morbidity and mortality. (26-28)

Patients in this study who died had $\sim 2.5$ fold higher peak NT-pro BNP than those who survived. A higher level of this biomarker suggests worsening right ventricular pressure overload as is seen in patients with worsening pulmonary hypertension. Other investigators have corroborated this finding. (29-31) In this study, patients with a peak NT-pro BNP $>8915 \mathrm{pg} / \mathrm{ml}$ had significantly higher mortality. These values are lower than those presented by Baptista et al. (32) in pediatric patients with congenital diaphragmatic hernia. In their study, patients with NT-pro BNP value $>11,500 \mathrm{pg} / \mathrm{ml}$ had worse prognosis. Also, the non-survivors had higher \% change in NT-pro BNP change during $\mathrm{PH}$ exacerbation and a higher drop in $\mathrm{pH}$ secondary to an acute rise in $\mathrm{pCO} 2$. Moreover, there was a significant positive correlation between peak NT-pro BNP concentration and peak pCO2. This confirms the observation that NT-pro BNP is influenced by changes in the underlying respiratory status. The correlation here was modest $(r=0.4)$ in part because NT-pro BNP is influenced by other factors including heart failure, blood pressure, heart rate, glomerular filtration rate and certain medications. (33)

Evaluating the echocardiographic parameters studied, Group 2 patients had a higher $\mathrm{RVSP} / \mathrm{SBP}(\%)$ ratio and a higher $\mathrm{S} / \mathrm{D}$ ratio. Studies evaluating these parameters in patients with $\mathrm{PH}$ have shown similar results. $(16,17,34)$ The RVSP/SBP ratio is graded as mild $(0.33-<0.66)$, moderate $(0.66-1)$ and severe $\mathrm{PH}(>1)$. In this cohort, patients with severe pulmonary hypertension had a higher likelihood of death. Also, the S/D ratio is a marker of systolic function and is elevated in patients with pulmonary hypertension. (16, 
35) It is particularly useful in patients with $\mathrm{PH}$ who don't have a complete tricuspid regurgitation jet. Children with a $\mathrm{S} / \mathrm{D}$ ratio $>1.7$ had significantly higher mortality which is similar to the study by Alkon et al. (16) evaluating S/D ratio in 47 children with PH. They found there was worse RV function, 6-minute walk distance, hemodynamic data and higher mortality in patients with $\mathrm{S} / \mathrm{D}$ ratio $>1.4$.

The results of this study confirm the hypothesis that NT-pro BNP increases with acute worsening of the respiratory status in infants and young children with $\mathrm{PH}$. Moreover, patients that subsequently died had higher NT-pro BNP concentrations and worse echocardiographic parameters of PH than long-term survivors.

\section{Study Limitations}

This was a retrospective study with a relatively small sample size. The NT-pro BNP levels were drawn for clinical indications and thus not at standardized intervals. To minimize this possible confounder, only blood gas and echocardiographic measurements done at specified times around the blood draws were analyzed. Also, this was a single center study, which might limit its generalizability. Due to the limited sample size, we were not able to achieve statistically significant cut-off values for $\%$ change in NT-pro BNP and RVSP/SBP (\%) despite the fact that there was a trend towards worse survival in patients with \%NT-pro BNP change $\geq 1291 \%$ and RVSP/SBP $(\%)$ ratio $\geq 64$.

\section{Conclusions}

Infants and young children with pulmonary hypertension have increased morbidity and mortality. NT-pro BNP is a useful biomarker for respiratory exacerbations in this population, and the S/D ratio a useful echocardiographic measure for pulmonary 
hypertension and both are significantly elevated in patients who did not survive. A rise in

NT-pro BNP may be in part secondary to worsening respiratory status. Serial

measurements may be useful to guide intensification of targeted therapy as an upward

trend in NT-pro BNP to $>8915 \mathrm{pg} / \mathrm{ml}$ carries a higher risk of death.

\section{Author Contributions}

Authors Shahnawaz M. Amdani and Robert D. Ross were involved in design, data

collection, analysis, forming initial draft of manuscript, critical revisions, and approval

of the final draft of the manuscript. Authors Ron L. Thomas and Muhammad Umair M.

Mian was involved in data collection, analysis, forming initial draft of manuscript,

critical revisions, and approval of the final draft of the manuscript.

\section{References}

1 Westerlind A, Wåhlander H, Lindstedt G, Lundberg PA, Holmgren D. Clinical signs of heart failure are associated with increased levels of natriuretic peptide types B and A in children with congenital heart defects or cardiomyopathy. Acta Paediatrica. 2004;93(3):340-5.

2 Dao Q, Krishnaswamy P, Kazanegra R, et al. Utility of B-type natriuretic peptide in the diagnosis of congestive heart failure in an urgent-care setting. Journal of the American College of Cardiology. 2001;37(2):379-85.

3 Von Lueder TG, Sangaralingham SJ, Wang BH, et al. Renin-Angiotensin Blockade Combined With Natriuretic Peptide System Augmentation. Circulation: Heart Failure. 2013;6(3):594-605.

4 Seino Y, Ogawa A, Yamashita T, et al. Application of NT - proBNP and BNP measurements in cardiac care: a more discerning marker for the detection and evaluation of heart failure. European journal of heart failure. 2004;6(3):295-300.

5 Troughton RW, Frampton CM, Yandle TG, Espine EA, Nicholls MG, Richards AM. Treatment of heart failure guided by plasma aminoterminal brain natriuretic peptide $(\mathrm{N}$ BNP) concentrations. The Lancet. 2000;355(9210):1126-30.

6 Weber M, Hamm C. Role of B-type natriuretic peptide (BNP) and NT-proBNP in clinical routine. Heart. 2006;92(6):843-9.

7 Auerbach SR, Richmond ME, Lamour JM, et al. BNP levels predict outcome in pediatric heart failure patients. Circulation: Heart Failure. 2010;3(5):606-11. 
8 Mir TS, Marohn S, Läer S, Eiselt M, Grollmus O, Weil J. Plasma concentrations of Nterminal pro-brain natriuretic peptide in control children from the neonatal to adolescent period and in children with congestive heart failure. Pediatrics. 2002;110(6):e76-e.

9 Farombi-Oghuvbu I, Matthews T, Mayne PD, Guerin H, Corcoran J. N-terminal pro-Btype natriuretic peptide: a measure of significant patent ductus arteriosus. Archives of

Disease in Childhood-Fetal and Neonatal Edition. 2008;93(4):F257-F60.

10 Joseph L, Nir A, Hammerman C, Goldberg S, Shalom EB, Picard E. N-terminal proB-type natriuretic peptide as a marker of bronchopulmonary dysplasia in premature infants. American journal of perinatology. 2010;27(05):381-6.

11 Reynolds EW, Ellington JG, Vranicar M, Bada HS. Brain-type natriuretic peptide in the diagnosis and management of persistent pulmonary hypertension of the newborn.

Pediatrics. 2004;114(5):1297-304.

12 Rudski LG, Lai WW, Afilalo J, et al. Guidelines for the echocardiographic assessment of the right heart in adults: a report from the American Society of Echocardiography. Journal of the American Society of Echocardiography. 2010;23(7):685-713. 13 Lang RM, Bierig M, Devereux RB, et al. Recommendations for chamber quantification. European journal of echocardiography. 2006;7(2):79-108.

14 Hatle L, Angelsen B, Tromsdal A. Non-invasive estimation of pulmonary artery systolic pressure with Doppler ultrasound. Heart. 1981;45(2):157-65.

15 Koestenberger M, Ravekes W, Everett AD, et al. Right ventricular function in infants, children and adolescents: reference values of the tricuspid annular plane systolic excursion (TAPSE) in 640 healthy patients and calculation of $\mathrm{z}$ score values. Journal of the American Society of Echocardiography. 2009;22(6):715-9.

16 Alkon J, Humpl T, Manlhiot C, McCrindle BW, Reyes JT, Friedberg MK. Usefulness of the right ventricular systolic to diastolic duration ratio to predict functional capacity and survival in children with pulmonary arterial hypertension. The American journal of cardiology. 2010;106(3):430-6.

17 Jone P-N, Ivy DD. Echocardiography in pediatric pulmonary hypertension. Frontiers in pediatrics. $2014 ; 2$.

18 Costeloe KL, Hennessy EM, Haider S, Stacey F, Marlow N, Draper ES. Short term outcomes after extreme preterm birth in England: comparison of two birth cohorts in 1995 and 2006 (the EPICure studies). Bmj. 2012;345:e7976.

19 Wilson-Costello D, Friedman H, Minich N, Fanaroff AA, Hack M. Improved survival rates with increased neurodevelopmental disability for extremely low birth weight infants in the 1990s. Pediatrics. 2005;115(4):997-1003.

20 Khemani E, McElhinney DB, Rhein L, et al. Pulmonary artery hypertension in formerly premature infants with bronchopulmonary dysplasia: clinical features and outcomes in the surfactant era. Pediatrics. 2007;120(6):1260-9.

21 An HS, Bae EJ, Kim GB, et al. Pulmonary hypertension in preterm infants with bronchopulmonary dysplasia. Korean circulation journal. 2010;40(3):131-6.

22 Ivy DD, Abman SH, Barst RJ, et al. Pediatric pulmonary hypertension. Journal of the American College of Cardiology. 2013;62(25):D117-D26.

23 Gladwin MT, Sachdev V, Jison ML, et al. Pulmonary hypertension as a risk factor for death in patients with sickle cell disease. New England Journal of Medicine.

2004;350(9):886-95. 
24 Bhat R, Salas AA, Foster C, Carlo WA, Ambalavanan N. Prospective analysis of pulmonary hypertension in extremely low birth weight infants. Pediatrics.

2012;129(3):e682-e9.

25 Dillon PW, Cilley RE, Mauger D, Zachary C, Meier A. The relationship of pulmonary artery pressure and survival in congenital diaphragmatic hernia. Journal of pediatric surgery. 2004;39(3):307-12.

26 Friesen CLH, Zurakowski D, Thiagarajan RR, et al. Total anomalous pulmonary venous connection: an analysis of current management strategies in a single institution. The Annals of thoracic surgery. 2005;79(2):596-606.

27 Rychik J, Rome JJ, Collins MH, DeCampli WM, Spray TL. The hypoplastic left heart syndrome with intact atrial septum: atrial morphology, pulmonary vascular histopathology and outcome. Journal of the American College of Cardiology. 1999;34(2):554-60.

28 Huddleston CB, Exil V, Canter CE, Mendeloff EN. Scimitar syndrome presenting in infancy. The Annals of thoracic surgery. 1999;67(1):154-9.

29 Van Albada ME, Loot FG, Fokkema R, Roofthooft MT, Berger RM. Biological serum markers in the management of pediatric pulmonary arterial hypertension. Pediatric research. 2008;63(3):321-7.

30 Takatsuki S, Wagner BD, Ivy DD. B - type Natriuretic Peptide and Amino - terminal Pro - B - type Natriuretic Peptide in Pediatric Patients with Pulmonary Arterial Hypertension. Congenital heart disease. 2012;7(3):259-67.

31 Chantal A, Tibboel D, Kraemer US. B-type natriuretic peptide as a parameter for pulmonary hypertension in children. A systematic review. European journal of pediatrics. 2015;174(10):1267-75.

32 Baptista MJ, Rocha G, Clemente F, et al. N-terminal-pro-B type natriuretic peptide as a useful tool to evaluate pulmonary hypertension and cardiac function in $\mathrm{CDH}$ infants. Neonatology. 2008;94(1):22-30.

33 Balion CM, Santaguida P, McKelvie R, et al. Physiological, pathological, pharmacological, biochemical and hematological factors affecting BNP and NT-proBNP. Clinical biochemistry. 2008;41(4):231-9.

34 Ramakrishna G, Sprung J, Ravi BS, Chandrasekaran K, McGoon MD. Impact of pulmonary hypertension on the outcomes of noncardiac surgery: predictors of perioperative morbidity and mortality. Journal of the American College of Cardiology. 2005;45(10):1691-9.

35 McCrary A, Malowitz J, Hornick C, et al. Differences in Eccentricity Index and Systolic-Diastolic Ratio in Extremely Low-Birth-Weight Infants with Bronchopulmonary Dysplasia at Risk of Pulmonary Hypertension. American journal of perinatology. 2016;2(01):057-62.

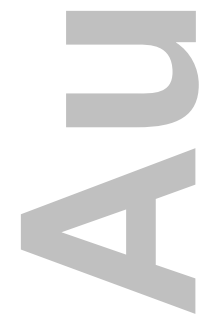


Figures (1a-c): These are graphs showing the relationship between pCO2 and NT-pro BNP levels in three pediatric patients with pulmonary hypertension

Figure 2. Kaplan-Meier survival curve comparing patients with highest NT-pro BNP

values $>8915 \mathrm{pg} / \mathrm{ml}$ vs. $\leq 8915 \mathrm{pg} / \mathrm{ml}$

Figure 3. Kaplan-Meier survival curve comparing patients with increase in NT-pro BNP value during $\mathrm{pH}$ exacerbation $\geq 1291 \%$ vs. $<1291 \%$

Figure 4. Kaplan-Meier survival curve comparing patients with RVSP/SBP ratio $\geq 64 \%$ vs. $<64 \%$

Figure 5. Kaplan-Meier survival curve comparing patients with $\mathrm{S} / \mathrm{D}$ ratio $>1.7$ vs. $\leq 1.7$. 
Table 1. Baseline characteristics of study cohort

\begin{tabular}{|c|c|}
\hline r & $\begin{array}{c}n=56 \\
\text { Mean }(95 \% C I), \text { Median (IQR) or } n(\%)\end{array}$ \\
\hline $\begin{array}{l}\text { Gestational age at birth (weeks) } \\
<28 \\
28-<32 \\
32-37 \\
>37\end{array}$ & $\begin{array}{c}28(50) \\
4(7.1) \\
4(7.1) \\
20(35.7)\end{array}$ \\
\hline Height $(\mathrm{cm})$ & $51(37.8-64.1)$ \\
\hline Weight (kg) & $3.9(1.2-6.6)$ \\
\hline BSA (m2) & $0.23(0.13-0.33)$ \\
\hline $\begin{array}{l}\text { Gender } \\
\mathrm{M} \\
\mathrm{F}\end{array}$ & $\begin{array}{l}28(50) \\
28(50)\end{array}$ \\
\hline $\begin{array}{l}\text { Ethnicity } \\
\text { African American } \\
\text { Caucasian } \\
\text { Hispanic/Other }\end{array}$ & $\begin{array}{c}37(66.1) \\
15(26.8) \\
4(7.1) \\
\end{array}$ \\
\hline $\begin{array}{l}\text { Underlying Diagnosis } \\
\text { BPD } \\
\text { Congenital Diaphragmatic Hernia } \\
\text { Down Syndrome } \\
\text { Congenital Heart Disease } \\
\text { Other (skeletal anomalies, omphalocele, } \\
\text { other syndromes) }\end{array}$ & $\begin{array}{l}35(62.5) \\
2(3.6) \\
1(1.8) \\
4(7.1) \\
14(25)\end{array}$ \\
\hline NT-pro BNP (pg/ml) & $1515(586-3633)$ \\
\hline $\begin{array}{l}\text { Support needed } \\
\text { Intubated } \\
\text { Tracheostomy } \\
\text { Sildenafil } \\
\text { Milrinone } \\
\text { Nitric oxide } \\
\text { ECMO }\end{array}$ & $\begin{array}{c}49(87.5) \\
23(41.1) \\
42(75) \\
23(41.1) \\
32(57) \\
4(7)\end{array}$ \\
\hline Length of ventilation & $70(41-99)$ \\
\hline Length of hospital stay & $140(110-170)$ \\
\hline $\begin{array}{l}\text { RVSP } \\
\text { Mildly increased } \\
\text { Moderately increased } \\
\text { Severely increased }\end{array}$ & $\begin{array}{l}26(46.4) \\
9(16.1) \\
21(37.5) \\
\end{array}$ \\
\hline $\begin{array}{l}\text { Patient status at discharge } \\
\text { Alive } \\
\text { Dead }\end{array}$ & $\begin{array}{l}47(83.9) \\
9(16.1)\end{array}$ \\
\hline
\end{tabular}


Table 2. Comparison of Survivors to Non-survivors

\begin{tabular}{|c|c|c|c|}
\hline 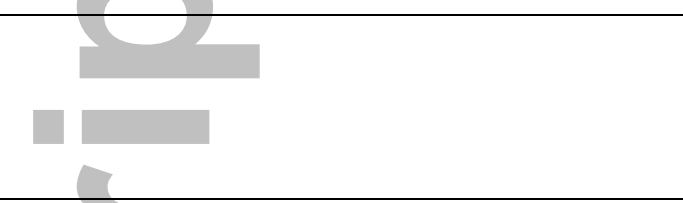 & $\begin{array}{c}\text { Group 1 } \\
\text { Survivors } \\
n=47 \\
\text { Mean } \pm \text { SD or } n(\%) \\
\end{array}$ & $\begin{array}{c}\text { Group } 2 \\
\text { Non-survivors } \\
\mathbf{n}=9 \\
\text { Mean } \pm \text { SD or } \mathbf{n}(\%) \\
\end{array}$ & p value \\
\hline $\begin{array}{l}\text { Gestational age at birth (weeks) } \\
<28 \\
28-<32 \\
32-37 \\
>37\end{array}$ & $\begin{array}{l}24(51.1) \\
3(6.4) \\
4(8.5) \\
16(34)\end{array}$ & $\begin{array}{l}4(44.4) \\
1(11.1) \\
0(0) \\
4(44.4)\end{array}$ & NS \\
\hline Height (cm) & $51.6 \pm 11.7$ & $54.6 \pm 11$ & NS \\
\hline Weight (kg) & $4.1 \pm 2.4$ & $4.8 \pm 2.7$ & NS \\
\hline BSA (m2) & $0.24 \pm 0.1$ & $0.27 \pm 0.1$ & $\mathrm{NS}$ \\
\hline $\begin{array}{l}\text { Gender } \\
\mathrm{M} \\
\mathrm{F}\end{array}$ & $\begin{array}{l}26(55.3) \\
21(44.7) \\
\end{array}$ & $\begin{array}{l}2(22.2) \\
7(77.8)\end{array}$ & NS \\
\hline $\begin{array}{l}\text { Ethnicity } \\
\text { African American } \\
\text { Caucasian } \\
\text { Hispanic/Other }\end{array}$ & $\begin{array}{c}32(68.1) \\
13(27.7) \\
2(4.2)\end{array}$ & $\begin{array}{l}5(55.6) \\
2(22.2) \\
2(22.2)\end{array}$ & NS \\
\hline $\begin{array}{l}\text { Underlying Diagnosis } \\
\text { Congenital Heart Disease } \\
\text { Other (BPD, Congenital Diaphragmatic } \\
\text { Hernia, Down Syndrome, skeletal } \\
\text { anomalies, omphalocele, other syndromes) }\end{array}$ & $\begin{array}{c}1(2.1) \\
46(97.9)\end{array}$ & $\begin{array}{l}3(33.3) \\
6(66.7)\end{array}$ & 0.01 \\
\hline $\begin{array}{l}\text { Highest NT-pro BNP during PH } \\
\text { exacerbation }\end{array}$ & $6885 \pm 9204$ & $16148 \pm 9669$ & $<0.05$ \\
\hline $\begin{array}{l}\text { \% decrease in pH during } \mathrm{PH} \\
\text { exacerbation }\end{array}$ & $2.5 \pm 2.1$ & $14 \pm 32$ & 0.01 \\
\hline $\begin{array}{l}\text { \% increase in pCO2 during } \mathrm{PH} \\
\text { exacerbation }\end{array}$ & $208 \pm 150$ & $406 \pm 247$ & $<0.05$ \\
\hline Length of yentilation & $49 \pm 90$ & $116 \pm 74$ & $<0.05$ \\
\hline $\begin{array}{l}\text { Support needed } \\
\text { Intubated } \\
\text { Tracheostomy } \\
\text { Sildenafil } \\
\text { Milrinone } \\
\text { Nitric Oxide } \\
\text { ECMO }\end{array}$ & $\begin{array}{c}40(85.1) \\
19(40.4) \\
33(70.2) \\
16(34) \\
24(51.1) \\
3(6.4) \\
\end{array}$ & $\begin{array}{l}9(100) \\
4(44.4) \\
9(100) \\
7(77.8) \\
8(88.9) \\
1(11.1)\end{array}$ & $\begin{array}{l}\mathrm{NS} \\
\mathrm{NS} \\
<0.1 \\
<0.05 \\
<0.05 \\
\mathrm{NS} \\
\end{array}$ \\
\hline $\begin{array}{l}\text { Echocardiographic parameters } \\
\text { S/D ratio } \\
\text { Maximum RVSP (mmHg) } \\
\text { RVSP/SBP ratio (\%) }\end{array}$ & $\begin{aligned} 1.6 & \pm 0.4 \\
56 & \pm 21 \\
46 & \pm 43\end{aligned}$ & $\begin{aligned} 2.2 & \pm 0.9 \\
73 & \pm 22 \\
76 & \pm 37\end{aligned}$ & $\begin{array}{l}<0.01 \\
<0.1 \\
0.05\end{array}$ \\
\hline $\begin{array}{l}\text { Atrial level shunting } \\
\text { Left to right } \\
\text { Right to Left } \\
\text { Bidirectional }\end{array}$ & $\begin{aligned} & 36(76.6) \\
& 1(2.1) \\
& 10(21.3) \\
&\end{aligned}$ & $\begin{array}{l}3(33.3) \\
1(11.1) \\
5(55.6)\end{array}$ & $<0.05$ \\
\hline
\end{tabular}




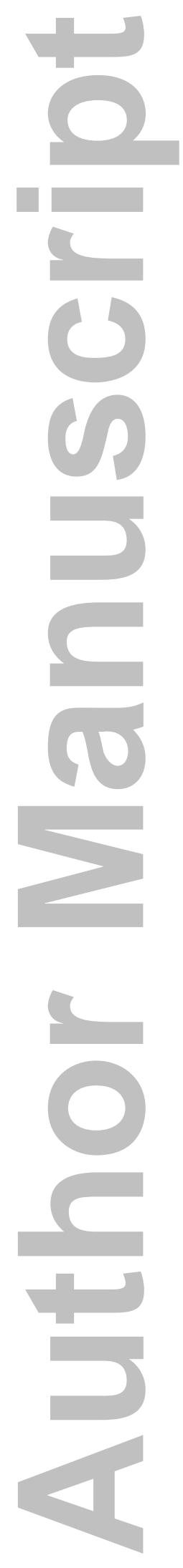

Congenital Heart Disease

This article is protected by copyright. All rights reserved. 


\section{Figure 1a.}

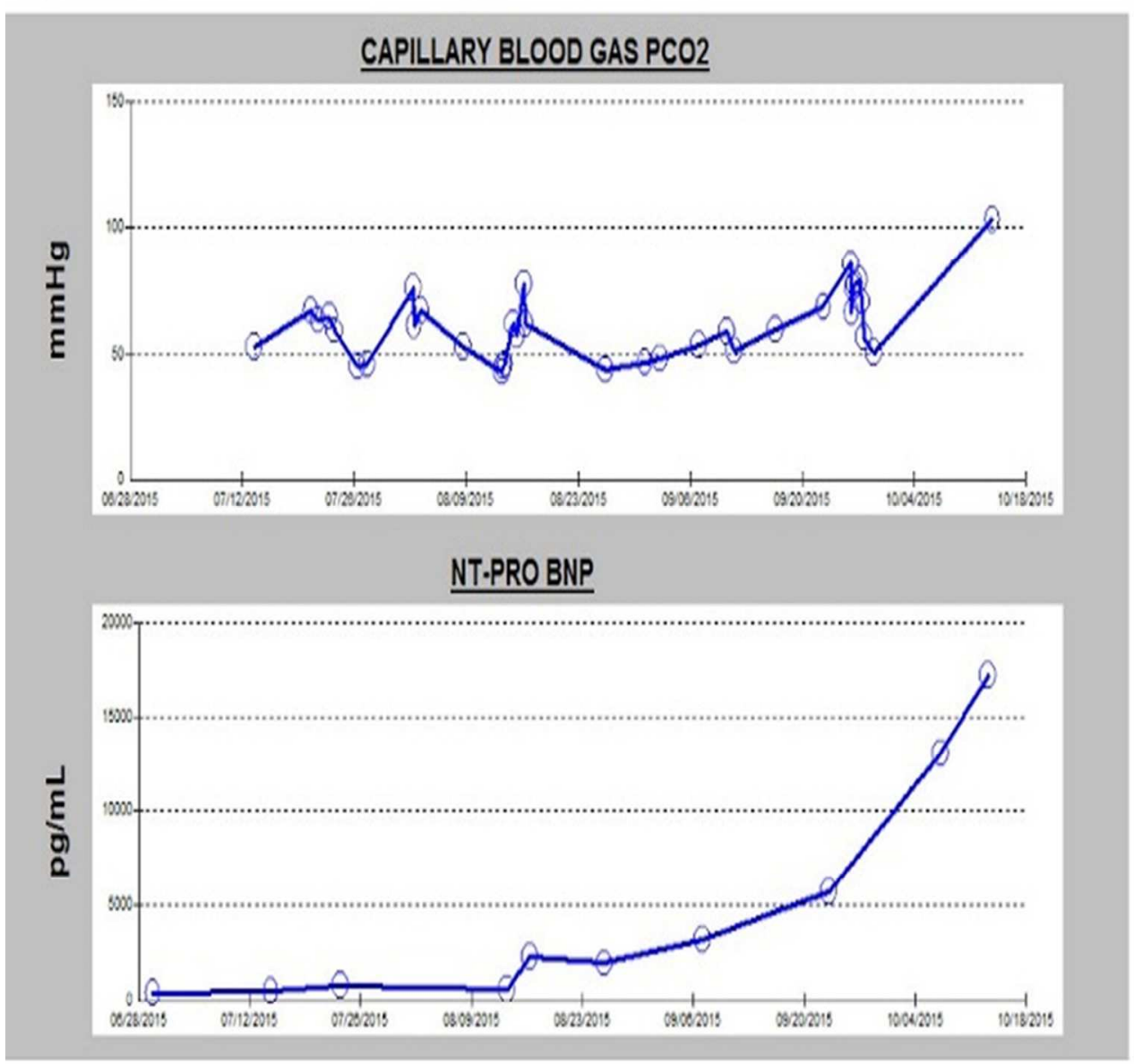

Figures (1a): These are graphs showing the relationship between pCO2 and NT-pro BNP levels in three pediatric patients with pulmonary hypertension

$$
67 \times 71 \mathrm{~mm}(300 \times 300 \mathrm{DPI})
$$

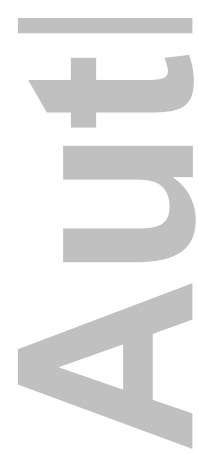


Figure 1b.

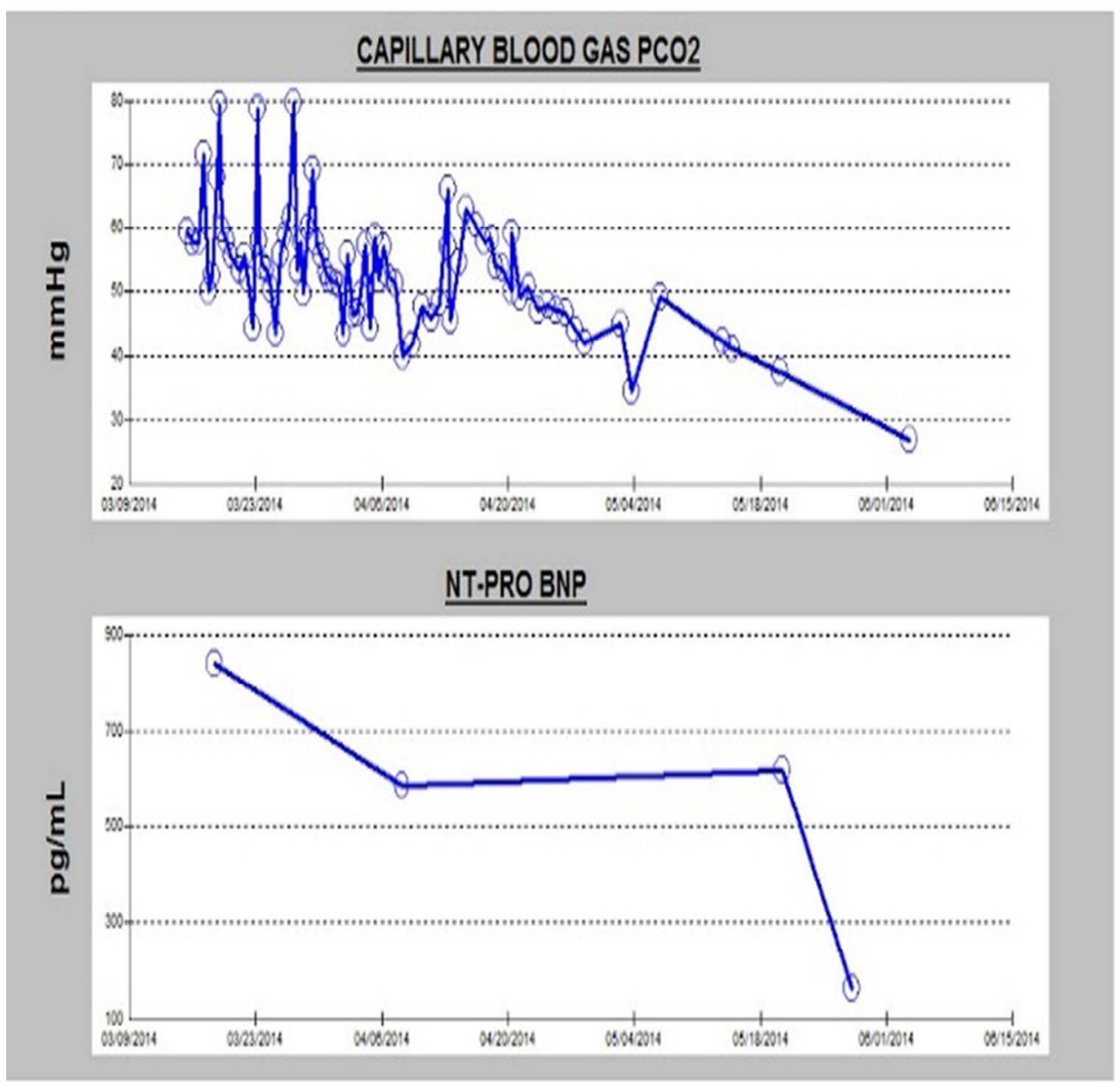

Figures (1b): These are graphs showing the relationship between pCO2 and NT-pro BNP levels in three pediatric patients with pulmonary hypertension

$69 \times 75 \mathrm{~mm}(300 \times 300 \mathrm{DPI})$ 
Figure 1c.

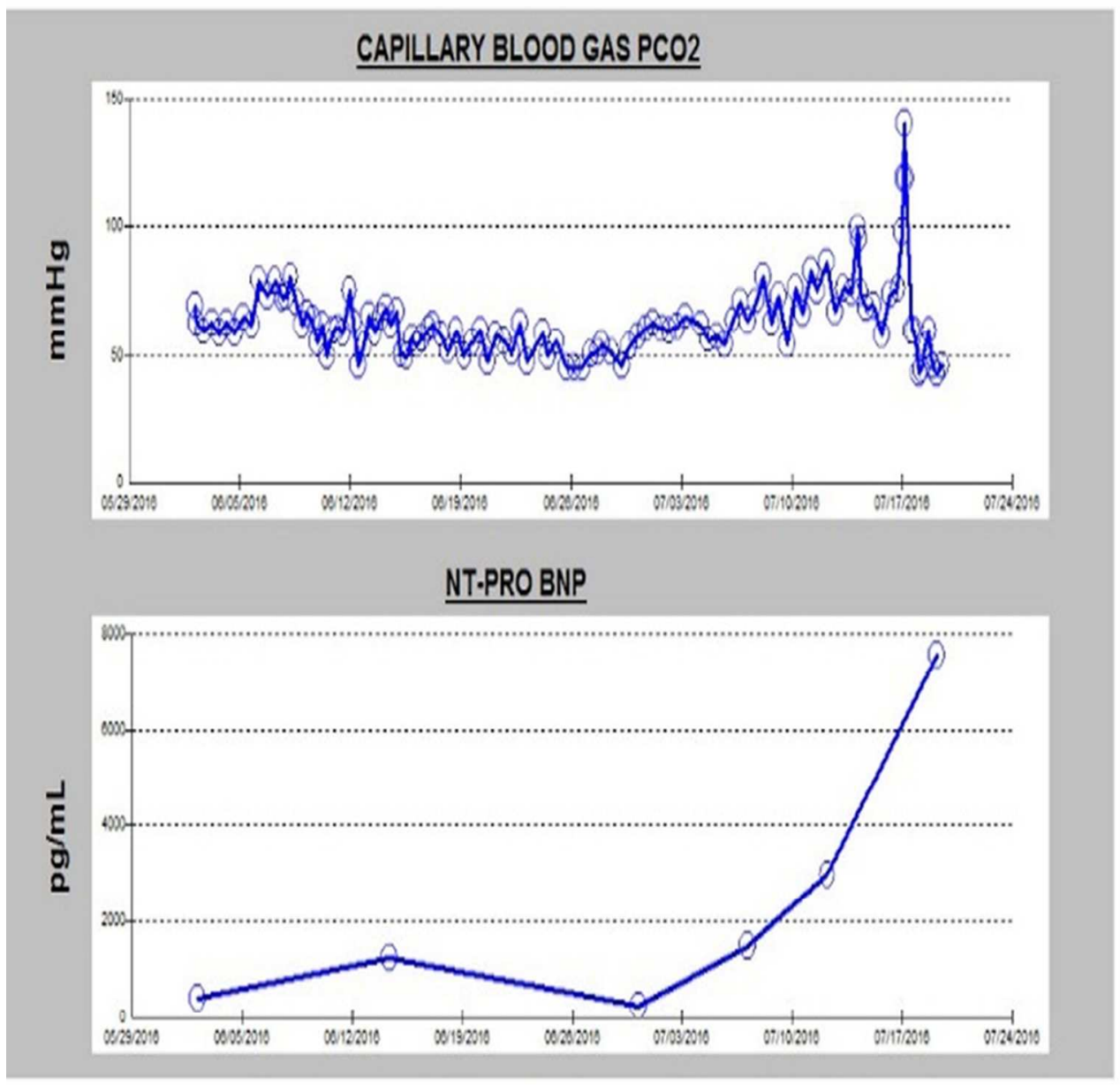

Figures (1c): These are graphs showing the relationship between pCO2 and NT-pro BNP levels in three pediatric patients with pulmonary hypertension

$69 \times 75 \mathrm{~mm}(300 \times 300 \mathrm{DPI})$ 


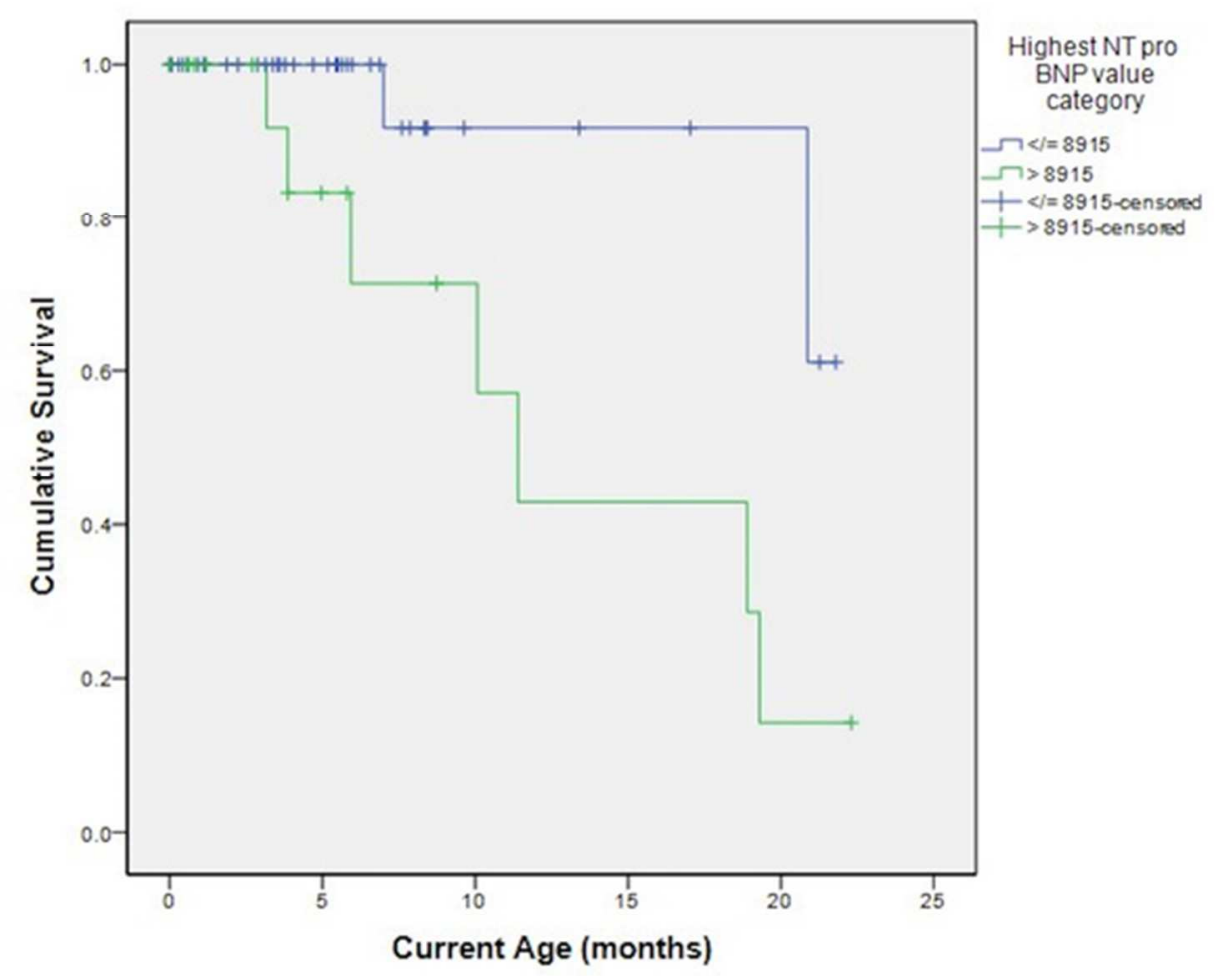

Figure 2. Kaplan-Meier survival curve comparing patients with highest NT-pro BNP values $>8915 \mathrm{pg} / \mathrm{ml}$ vs. $\leq 8915 \mathrm{pg} / \mathrm{ml}$

$52 \times 42 \mathrm{~mm}(300 \times 300 \mathrm{DPI})$ 


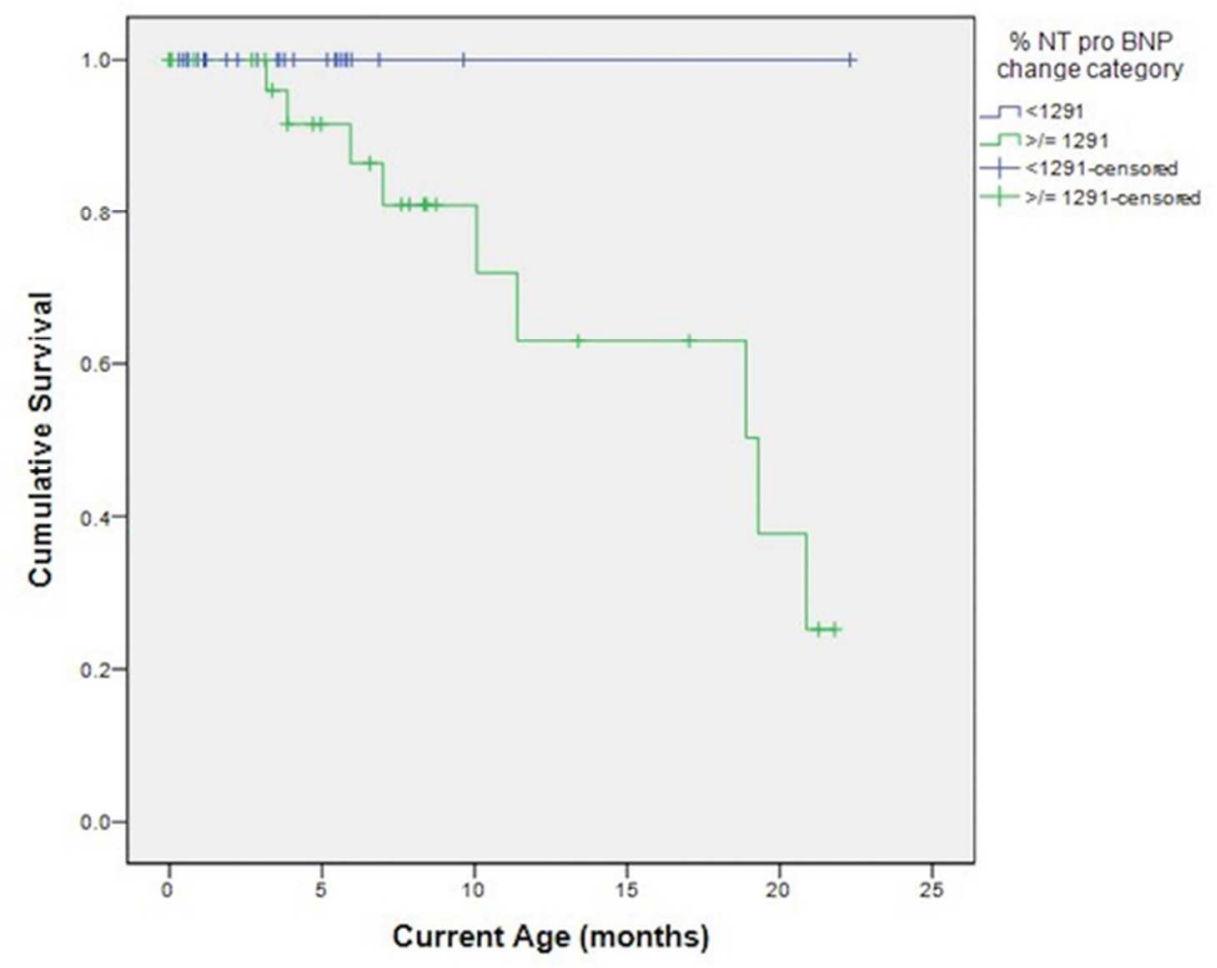

Figure 3. Kaplan-Meier survival curve comparing patients with increase in NT-pro BNP value during $\mathrm{pH}$ exacerbation $\geq 1291 \%$ vs. $<1291 \%$

$56 \times 45 \mathrm{~mm}(300 \times 300$ DPI $)$ 


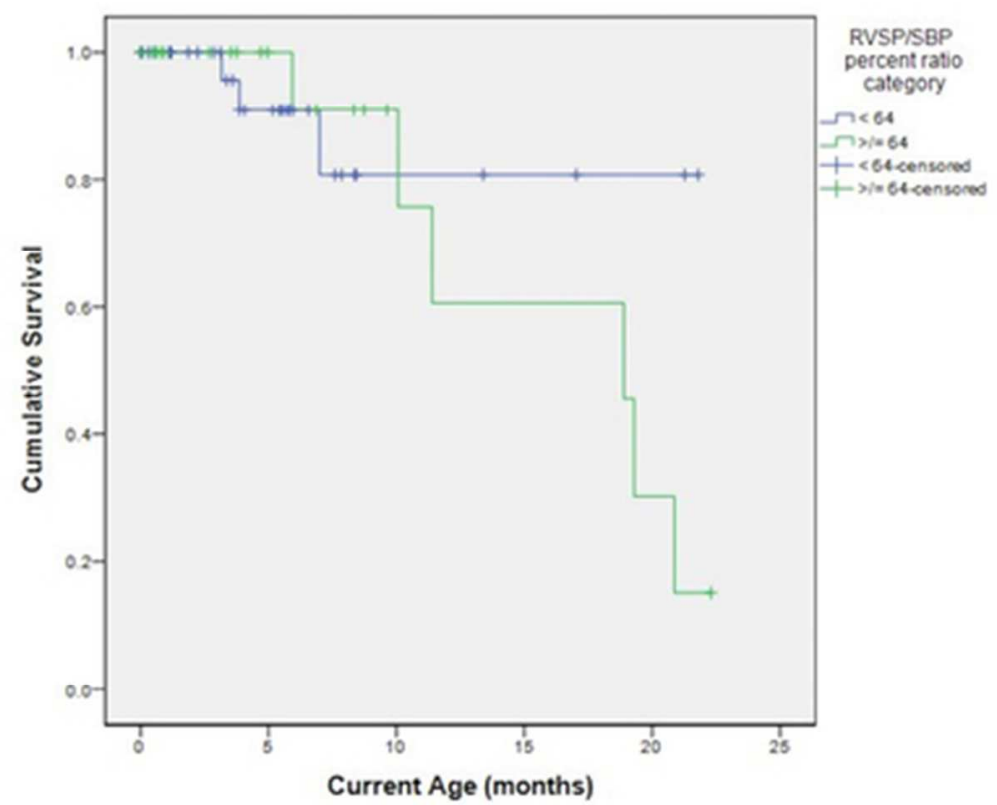

Figure 4. Kaplan-Meier survival curve comparing patients with RVSP/SBP ratio $\geq 64 \%$ vs. $<64 \%$

$35 \times 28 \mathrm{~mm}(300 \times 300 \mathrm{DPI})$ 


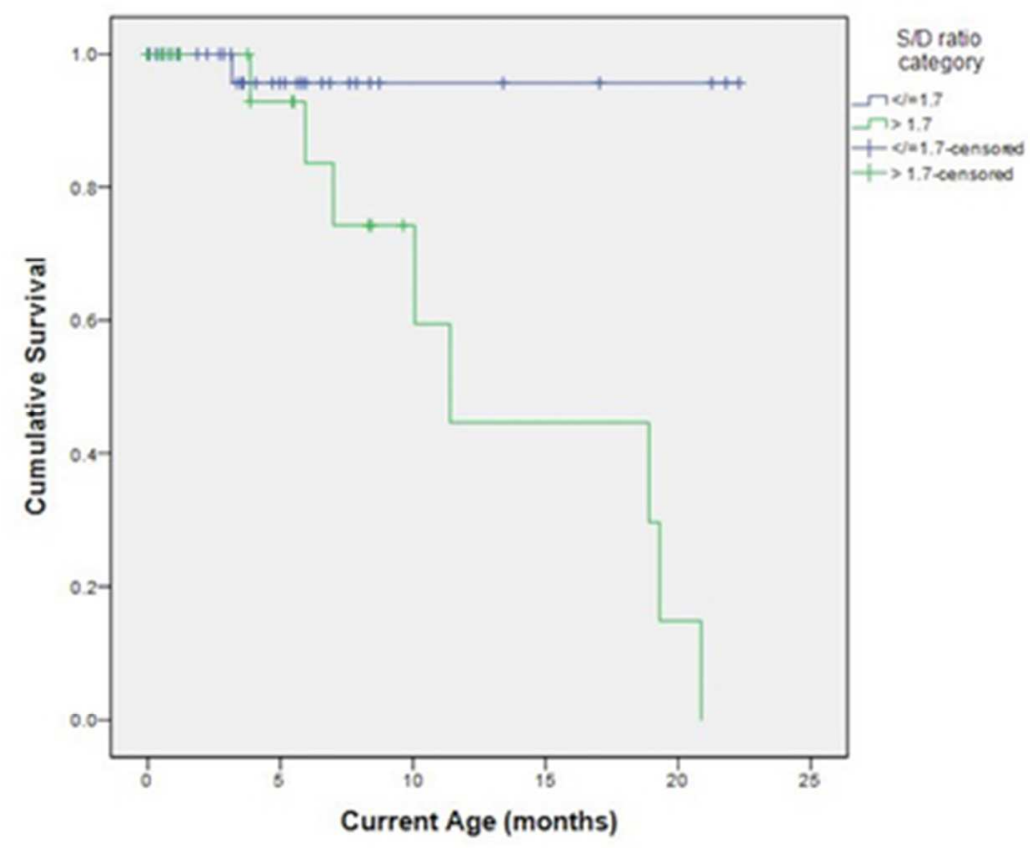

Figure 5. Kaplan-Meier survival curve comparing patients with S/D ratio $>1.7$ vs. $\leq 1.7$ $36 \times 29 \mathrm{~mm}(300 \times 300 \mathrm{DPI})$ 